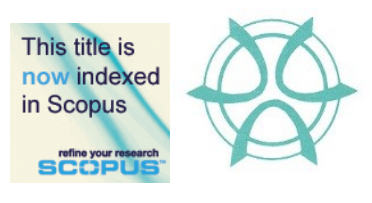

\title{
RESIDENTIAL BUILDING QUALITY MEASUREMENT AND THE RELATIONSHIP WITH HOUSE PRICES: A STUDY OF HOUSES IN KLANG
}

\section{Muhamad Hilmi Mohamad @ Masri', Mohd Farid Sa'ad ${ }^{2}$, Najma Azman ${ }^{3}$, Mohd Hasrol Haffiz Aliasak ${ }^{4}$}

\author{
Department of Built Environment Studies and Technology, \\ Faculty of Architecture, Planning and Surveying \\ UNIVERSITI TEKNOLOGI MARA PERAK BRANCH, \\ 32610 SERI ISKANDAR, PERAK
}

\begin{abstract}
This research focuses on the particular aspect of residential building quality and aims to measure the relationship that affects houses prices in Klang. The researcher through the problem statement and literature review has noted that respondents have knowledge in measuring the quality of their own house, but measurement must be conducted on an empirical basis with evidence. The main research objectives were to identify residential building quality and to measure the residential building quality effect on houses prices. The sampling of the research was conducted on fifty houses, and the measurement was conducted with the help of Regression Analysis. The results obtained show a significant relationship between higher quality of residential buildings and higher prices that can be commanded. The findings also could help to improve the estimation of value for new and older houses in the sampled areas.
\end{abstract}

Keywords: quality measurement, residential house price, residential quality

\footnotetext{
${ }^{1}$ Senior Lecturer at University Teknologi MARA Email: muhamadhilmi@uitm.edu.my
} 
PLANNING MALAYSIA

Journal of the Malaysia Institute of Planners (2021)

\section{INTRODUCTION}

In finding out the aspects of residential houses to be measured in the research, first, the researcher has to outline the arguments addressed by other researchers relating to residential buildings and the relationship with the prices. For the aspect of houses bought by buyers, most of the respondents' understanding was that higher house prices equate to higher house quality. Nevertheless, in urban areas, a high house prices sometimes did not correlate with the quality that the buyers received in turn making the purchase to be perceived as unsatisfying. This statement was also noted by Mohit, Ibrahim, \& Rashid, (2010) stating that buyers who purchased houses from property developers and other sub-sale house sellers were not content with the qualities but proving it in an empirical way of low quality was difficult. Fauzi, Yusof, \& Abidin, (2012) noted also that low residential building quality as was seen in Malaysia and buyers have no other choice than to receive their bought house from the property developers.

$\mathrm{Mu}$, (2016) also stated that residential building quality can be neglected as developers usually did not measure properly their built houses before handing them off to buyers. Emmanuel, (2012) through his research also noted developers might enunciate their houses were of high quality but not being backed by any empirical data or benchmarking guidelines. Amin, Zubaidah, Abdul, \& Kassim, (2015) also reported that residential building quality as was usually complained by house buyers. However, little standardised action was taken by developers in rectifying the issue. For these reasons, the researcher believes that there is a major research gap that needs to be addressed for the benefit of house buyers.

Iwata \& Yamaga, (2008) also addressed that house buyers were not satisfied with the quality of their houses after moving in as the quality level was found to be unsatisfactory. These were also supported by Shuid, (2015) that stated that houses with sub-par quality were delivered to house buyers and eventually, many repairs had to be conducted afterwards. Bø (2018) also noted that house buyers often compare their residential buildings in other residential areas and it leads to some understanding regarding the quality of houses that they received. Based on the problems above, the researcher feels that the residential building quality needs to be addressed, and their relationship with the prices paid needs to be measured for the benefit of house buyers. 
MuhamadHilmi Mohamad@Masri, Mohd Farid Sa'ad, Najma Azman, Mohd Hasrol Haffiz Aliasak

Residential Building Quality Measurement and The Relationship with House Prices: A Study of Houses in Klang

\section{LITERATURE REVIEW \\ Residential Building Qualities}

The quality of residential building is needed as it will look into the material aspect of the houses, and the buyers can ensure several elements to be available in their houses. Physicality can be reviewed as their quality, physical elements and functionality thus helping to develop a good quality residential area (Yazdanfar $\&$ Nazari, 2015). Besides this, Fattah et al., (2020) also denoted that residential dwelling features also contribute towards quality especially in the neighbourhood and residential areas. The researchers addressed the importance of various elements to be studied and measured thoroughly to achieve the outlined objectives.

The physicality of houses must be explained in terms of elements of functionality and housing quality correlations. House quality, thus, also needs to be improved for the well-being of house buyers. (Behzadfar \& Saneei, 2012). Urban environments inclusion of residential buildings in Malaysia also needs to be justified and included as part of the measurement. The physical housing dimensions need to be placed where they become vital in dealing with the livelihood of house buyers and their satisfactions in a residential development (Elshater, 2012). Other than that, stakeholders also need to consider buyer's needs as stakeholders develop safety and accessibility regarding their housing conditions (Gobster \& Westphal, 2004).

Hassan et al., (2021) in their research also found that there is a significant relationship between house prices and housing expenditure to maintain the building. The researchers saw this as part of residential building features that were also needed to become part of measurement indicators. Knowing house buyers needs will then align with optimal housing physical conditions and buyers can be satisfied with the residential building quality level and this can increase their live quality (Hamzehnejad et al., 2015).

Amenities of housing need to be looked at as the measurement of housing conditions such as external exterior, interior aspects, and community features of housing (Ezgi \& Kahraman, 2013). Other than that, elements of amenities which include noise level, and transportation were built inside housing areas but due to financial limitations of buyers, these sometimes need to be sacrificed (Hui et al., 2007).

\section{Literature Background of Residential Building Qualities relationship with House Prices}

Based on the previous discussions, several research have shown relevance towards showing that residential building qualities that have relationships with house prices. Adeoye, (2016) believed that buyers can perceive house quality subjectively and houses with important qualities that need to be measured. Based on the explanation given by the previous researcher, it can be perceived that 
residential building quality can be assessed through observation and perception, and house buyers can help in determining residential building quality level.

The discussion above was also supported by M. H. b M. @ Masri, Nawawi, Safian, \& Saleh, (2017), with their research on the quality level that has measured the quality level of the residential building based on observations. $\mathrm{N}$. Hamzah et al., (2011) in their statement also noted that the residential building quality must be measured thoroughly for best results of the relationship.

Morenikeji et al., (2017) also stated that housing quality needs to be discussed so that the measurement towards quality level will be sought and analysed rigorously. Another explanation made available from Manley, Ham, Bailey, \& Simpson, (2013) verifies that residential building with high quality generally lacks the conditions afflicted by low quality work, lacklustre residential areas design and urban community issues. This information is needed as it will help to find out the influence on residential building quality measurement. Overall, the researcher intends that residential building quality to be understood, and the measurement of it on prices will be carried out in the research.

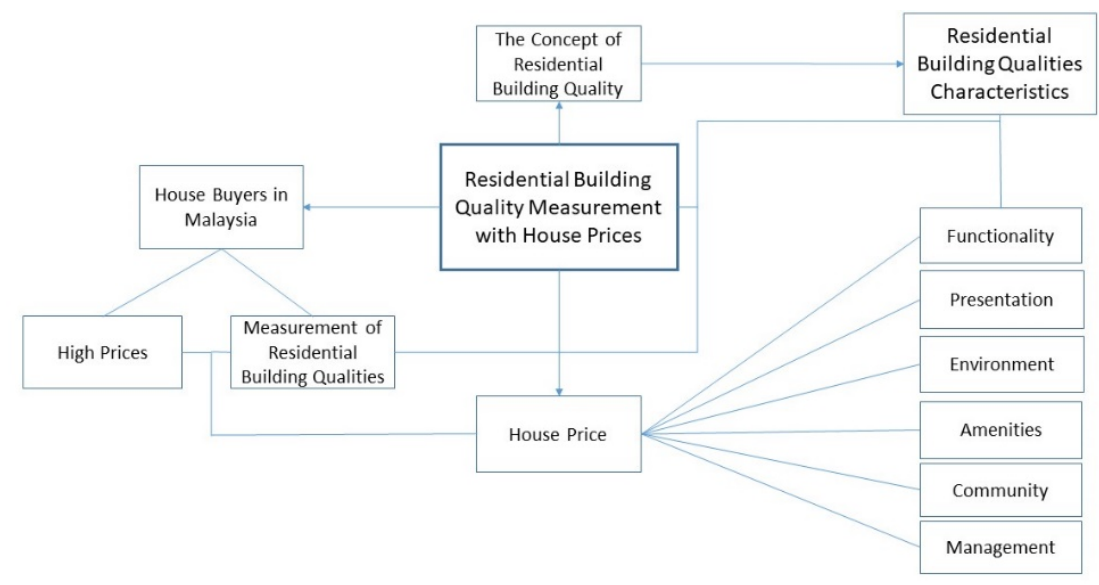

Figure 1: Theoretical Framework of Residential Building Quality Measurement with House Prices 
MuhamadHilmi Mohamad@Masri, Mohd Farid Sa'ad, Najma Azman, Mohd Hasrol Haffiz Aliasak Residential Building Quality Measurement and The Relationship with House Prices: A Study of Houses in Klang

\section{METHODOLOGY}

Observation Form

As for the case study included in the sampling of the research, fifty units of observation forms were laid out for the measurement of residential building qualities. Elements that include the characteristics of functionality, presentation, environment, amenities, community, and management. The next step of the survey conducted by the researcher aims to measure the relationship that affects houses prices in Klang. As objective one has been achieved from the review of literature, elements from the first objective to measure the quality level of the characteristics were included. The observation was conducted on the selected fifty houses in ten residential areas in the district of Klang using convenience sampling. The researcher personally conducted the observation form survey to reduce errors that may occur with using research assistants. The data obtained by the researcher's survey also must be low in error in allowing the measurement of the residential building quality. The subsequent data analysis will then be measured with the house prices that were obtained from NAPIC, and the relationship will be measured through the Regression Analysis.

\section{Regression Analysis}

For this research analysis, this section will show the analysis relating to both variables independent and dependent that will be carried out by regression analysis. To complete the regression analysis, steps on homoscedasticity, normality, linearity, and outlier's identification must be fulfilled, thus allowing regression analysis to be carried out. The empirical data collected then were analysed using the SPSS 22.0 statistics software and help to identify the residential building characteristic's quality relationship with prices. Table 1 explains the framework of the research being conducted, and Tables 2 to 7 will show the analysis values of the regression together with the findings generated from it.

Table 1: Research Method and Sampling

\begin{tabular}{|c|c|c|c|}
\hline $\begin{array}{l}\text { Stage of } \\
\text { Research }\end{array}$ & $\begin{array}{l}\text { Research } \\
\text { Objective }\end{array}$ & $\begin{array}{l}\text { Research Methods \& } \\
\text { Types of Data }\end{array}$ & Selection of Sample \\
\hline Stage 1 & $\begin{array}{l}\text { 1. To identify } \\
\text { residential } \\
\text { building quality } \\
\text { characteristics }\end{array}$ & $\begin{array}{l}\text { Quantitative Data } \\
\text { Instrument: } \\
\text { - Observation Forms } \\
\text { Respondents: } \\
\text { - One observation } \\
\text { per house } \\
\text { Sample: } \\
\text { Convenience Sampling } \\
\text { - Ten households per } \\
\text { - } \quad \text { residential area } \\
\text { Total 50 } \\
\text { households } \\
\text { involved }\end{array}$ & $\begin{array}{cl}\text { Sampling of Houses } \\
\text { 1. } & \text { Bandar Bukit Raja (DS) } \\
\text { 2. } & \text { Taman Klang Utama (SS) } \\
\text { 3. } & \text { Aman Perdana (DS) } \\
\text { 4. } & \text { Bandar Bukit Tinggi (DS) } \\
\text { 5. } & \text { Bandar Botanic (DS) } \\
\text { 6. } & \text { Taman Sentosa (SS) } \\
\text { 7. } & \text { Taman Berkeley (SS) } \\
\text { 8. } & \text { Bandar Puteri (DS) } \\
\text { 9. } & \text { Taman Sri Andalas (DS) } \\
\text { 10. } & \text { Taman Bayu Perdana (DS) }\end{array}$ \\
\hline
\end{tabular}




\begin{tabular}{|c|c|c|c|}
\hline & & $\begin{array}{ll}- & \text { Double (DS) and } \\
& \text { Single Storey (SS) } \\
\text { Terrace Houses }\end{array}$ & \\
\hline Stage 2 & $\begin{array}{l}\text { 2. To measure the } \\
\text { residential } \\
\text { building quality } \\
\text { characteristics } \\
\text { effect on houses } \\
\text { prices. }\end{array}$ & $\begin{array}{l}\text { Significant Findings: } \\
\text { Instrument: } \\
\text { - } \quad \text { Regression } \\
\text { Analysis } \\
\text { - } \quad \text { SPPS Software } \\
\quad \text { Version } 22\end{array}$ & $\begin{array}{ll}\text { 1. } & \text { Functionality } \\
\text { 2. } & \text { Presentation, } \\
\text { 3. } & \text { Environment } \\
\text { 4. } & \text { Amenities, } \\
\text { 5. } & \text { Community, } \\
\text { 6. } & \text { Management, } \\
\text { 7. } & \text { House Prices }\end{array}$ \\
\hline
\end{tabular}

\section{FINDINGS AND DISCUSSION}

Table 2: Regression Analysis of Functionality and Prices

\begin{tabular}{lllllll}
\hline \multicolumn{7}{l}{ Regression Analysis between Functionality and Prices } \\
\hline \multicolumn{5}{c}{ Double Storey Houses } & \multicolumn{4}{l}{ Single Storey Houses } \\
\hline \multirow{3}{*}{ Functionality } & B & t & Sig. & B & t & Sig. \\
\hline$R^{2}$ & 0.177 & 1.128 & 0.029 & 0.153 & 1.152 & 0.021 \\
$F$ & 0.016 & & 0.018 & \\
Sig. & $27.63^{* *}$ & & $25.67^{* *}$ & \\
\hline \multicolumn{7}{c}{0.021} \\
\end{tabular}

Table 2 shows the summary statistics using regression regarding Functionality and house price. The regression results show that the F-Values for Double and Single Storey House models to be statistically significant at 0.01 level. The regression models explain only $1.6 \%$ (double-storey houses) and $1.8 \%$ (single storey houses) variations in the house prices. The coefficient of the Functionality Variable is positive for the Double Storey Houses $(0.177)$ but the t-value at 1.128 is not statistically significant at 0.05 level. Therefore, Functionality is not a significant factor affecting Double Storey House prices.

For the Single Storey House model, the coefficient of the Functionality Variable is positive (0.153) but the $t$-value at 1.152 is not statistically significant at 0.05 level. Therefore, Functionality is not a significant factor affecting Single Storey House prices.

The result shows that the relationship between functionality and prices is not significant. Functionality, therefore, was not an important element in the observation of the research. The aspect of the functionality of houses was expected to fulfil quality houses but not as a priority. The functionality quality level of residential building quality only contributed a small amount of increase of house price. 
MuhamadHilmi Mohamad@Masri, Mohd Farid Sa'ad, Najma Azman, Mohd Hasrol Haffiz Aliasak Residential Building Quality Measurement and The Relationship with House Prices: A Study of Houses in Klang

Table 3: Regression Analysis of Presentation and Prices

\begin{tabular}{|c|c|c|c|c|c|c|}
\hline & \multicolumn{3}{|c|}{ Double Storey Houses } & \multicolumn{3}{|c|}{ Single Storey Houses } \\
\hline & $\mathbf{B}$ & t & Sig. & $\mathbf{B}$ & t & Sig. \\
\hline Presentation & 0.118 & 1.022 & 0.323 & 0.131 & 1.121 & 0.292 \\
\hline$R^{2}$ & 0.007 & & & 0.008 & & \\
\hline$F$ & $12.57 * *$ & & & $10.76^{* *}$ & & \\
\hline Sig. & 0.323 & & & 0.292 & & \\
\hline
\end{tabular}

Table 3 shows the summary statistics using regression regarding Presentation and house price. The regression results show that the F-Values for Double and Single Storey House models to be statistically significant at 0.01 level. The regression models explain only $0.7 \%$ (double-storey houses) and $0.8 \%$ (single storey houses) variations in the house prices. The coefficient of the Presentation Variable is positive for the Double Storey Houses (0.118) but the t-value at 1.022 is not statistically significant at 0.05 level. Therefore, Presentation is not a significant factor affecting Double Storey House prices.

For the Single Storey House model, the coefficient of the Presentation Variable is positive (0.131) but the t-value at 1.121 is not statistically significant at 0.05 level. Therefore, Presentation is not a significant factor affecting Single Storey House prices.

From the result, the aspect of presentation does not have any significant effect on house prices. It can be concluded that buyers did not pay much attention aspect of the presentation of the houses. As in new houses, house buyers have to rely on the information given on the houses by the developers rather than the actual house itself as there is no physical completion. For second-hand houses, perceived observation and own inspection of the houses were only needed for the information of buyers and does not have much effect on prices.

Table 4: Regression Analysis of Environment and Prices

\begin{tabular}{|c|c|c|c|c|c|c|}
\hline \multicolumn{7}{|c|}{ Regression Analysis between Environment and Prices } \\
\hline & \multicolumn{3}{|c|}{ Double Storey Houses } & \multicolumn{3}{|c|}{ Single Storey Houses } \\
\hline & $\mathbf{B}$ & $\mathbf{t}$ & Sig. & B & $\mathbf{t}$ & Sig. \\
\hline Environment & 0.485 & $3.584 * *$ & 0.000 & 0.435 & $3.415^{* *}$ & 0.000 \\
\hline$R^{2}$ & 0.154 & & & 0.142 & & \\
\hline$F$ & $51.23 * *$ & & & $47.88 * *$ & & \\
\hline Sig. & 0.000 & & & 0.000 & & \\
\hline
\end{tabular}


Table 4 shows the summary statistics by using regression regarding Environment and house price. The regression result shows that the F-value for Double and Single Storey House models of 51.23 and 47.88 are statistically significant at 0.01 level. The regression model explains $15.4 \%$ (double-storey houses) and $14.2 \%$ (single storey houses) of the variation in the dependent variable. The coefficient of the Environment Variable is positive for the Double Storey Houses (0.485) and statistically significant at 0.01 level. Therefore, the coefficient is significantly different from zero at 0.01 level indicating Environment to be a significant factor affecting Double Storey House prices. A 1 per cent change in the value of the Environment will cause an increase of 0.485 per cent in Double Storey House prices.

For the Single Storey House model, the coefficient of the Environment Variable is positive $(0.435)$ and statistically significant at 0.01 level. Therefore, the coefficient is significantly different from zero at 0.01 level indicating Environment is a significant factor affecting Single Storey House prices. A 1 per cent change in the value of the Environment will cause an increase of 0.435 per cent in Single Storey House prices.

The analysis shows that there is a significant relationship between the two elements. Buyers in a way can be understood by the researcher to purchase a home in a holistic manner encompassing larger areas of the development. An emphasis on the environment shows that house buyers value their surrounding areas and look for a higher quality of planned residential developments.

Table 5: Regression Analysis of Amenities and Prices

\begin{tabular}{|c|c|c|c|c|c|c|}
\hline \multicolumn{7}{|c|}{ Regression Analysis between Amenities } \\
\hline & \multicolumn{3}{|c|}{ Double Storey Houses } & \multicolumn{3}{|c|}{ Single Storey Houses } \\
\hline & $\mathbf{B}$ & $\mathbf{t}$ & Sig. & $\mathbf{B}$ & $\mathbf{t}$ & Sig. \\
\hline \multirow[t]{2}{*}{ Amenities } & 0.291 & $2.877 * *$ & 0.001 & 0.277 & $2.983 *$ & 0.000 \\
\hline & & & & & $*$ & \\
\hline$R^{2}$ & 0.077 & & & 0.073 & & \\
\hline \multirow[t]{2}{*}{$F$} & $30.23 * *$ & & & $32.72 *$ & & \\
\hline & & & & $*$ & & \\
\hline Sig. & 0.001 & & & 0.000 & & \\
\hline
\end{tabular}


MuhamadHilmi Mohamad@Masri, Mohd Farid Sa'ad, Najma Azman, Mohd Hasrol Haffiz Aliasak Residential Building Quality Measurement and The Relationship with House Prices: A Study of Houses in Klang

Table 5 shows the summary statistics using regression regarding Amenities and house price. The regression result shows that the F-value for Double and Single Storey House models of 30.23 and 32.72 are statistically significant at 0.01 level. The regression model explains $7.7 \%$ (double-storey houses) and $7.3 \%$ (single storey houses) of the variation in the dependent variable. The coefficient of the Amenities Variable is positive for the Double Storey Houses (0.291) and statistically significant at 0.01 level. Therefore, the coefficient is significantly different from zero at 0.01 level indicating Amenities is a significant factor affecting Double Storey House prices. A 1 per cent change in the value of Amenities will cause an increase of 0.291 per cent in Double Storey House prices. For the Single Storey House model, the coefficient of the Amenities Variable is positive (0.277) and statistically significant at 0.01 level. Therefore, the coefficient is significantly different from zero at 0.01 level indicating Amenities is a significant factor affecting Single Storey House prices. A 1 per cent change in the value of Amenities will cause an increase of 0.277 per cent in Single Storey House prices.

The analysis shows that there is a significant relationship between the two elements. The provisions given in a residential area development will contribute to higher house prices and also higher quality of houses.

Table 6: Regression Analysis of Community and Prices

\begin{tabular}{|c|c|c|c|c|c|c|}
\hline \multicolumn{7}{|c|}{ Regression Analysis between Community and Prices } \\
\hline & \multicolumn{3}{|c|}{ Double Storey Houses } & \multicolumn{3}{|c|}{ Single Storey Houses } \\
\hline & B & t & Sig. & B & $\mathbf{t}$ & Sig. \\
\hline Community & 0.177 & 1.258 & 0.001 & 0.184 & 1.387 & 0.001 \\
\hline$R^{2}$ & 0.016 & & & 0.013 & & \\
\hline$F$ & $20.55 * *$ & & & $21.85 * *$ & & \\
\hline Sig. & 0.001 & & & 0.001 & & \\
\hline
\end{tabular}

Table 6 shows the summary statistics using regression regarding Community and house price. The regression results show that the F-Values for Double and Single Storey House models are statistically significant at 0.01 level. The regression models explain only $1.6 \%$ (double-storey houses) and $1.3 \%$ (single storey houses) variations in the house prices. The coefficient of the Community Variable is positive for the Double Storey Houses (0.177) but the t-value at 1.258 is not statistically significant at 0.05 level. Therefore, Community is not a significant factor affecting Double Storey House prices.

For the Single Storey House model, the coefficient of the Community Variable is positive $(0.184)$ but the t-value at 1.387 is not statistically significant 
at 0.05 level. Therefore, Community is not a significant factor affecting Single Storey House prices.

From the analysis, it was found out that the two elements do not have any significant relationship with one another. The findings shows that the social aspect is not an important quality factor that can influence the price of houses.

Table 7: Regression Analysis of Management and Prices

\begin{tabular}{|c|c|c|c|c|c|c|}
\hline & \multicolumn{3}{|c|}{ Double Storey Houses } & \multicolumn{3}{|c|}{ Single Storey Houses } \\
\hline & $\mathbf{B}$ & t & Sig. & B & t & Sig. \\
\hline Management & 0.452 & $2.873 * *$ & 0.000 & 0.409 & $2.325^{*}$ & 0.000 \\
\hline$R^{2}$ & 0.118 & & & 0.134 & & \\
\hline$F$ & $34.75^{* *}$ & & & $37.93^{* *}$ & & \\
\hline Sig. & 0.000 & & & 0.000 & & \\
\hline
\end{tabular}

Table 7 shows the summary statistics using regression of house prices on Management. The regression result shows that the F-value for Double and Single Storey House models of 34.75 and 37.93 are statistically significant at 0.01 level. The regression model explains $11.8 \%$ (double-storey houses) and $13.4 \%$ (single storey houses) of the variation in the dependent variable. The coefficient of the Management Variable is positive for the Double Storey Houses (0.452) and statistically significant at 0.01 level. Therefore, the coefficient is significantly different from zero at 0.01 level indicating Management is a significant factor affecting Double Storey House prices. A 1 per cent change in the value of Management will cause an increase of 0.452 per cent in Double Storey House prices.

For the Single Storey House model, the coefficient of the Management Variable is positive (0.409) and statistically significant at 0.05 level. Therefore, the coefficient is significantly different from zero at 0.05 level indicating Management is a significant factor affecting Single Storey House prices. A 1 per cent change in the value of Management will cause an increase of 0.409 per cent in Single Storey House prices.

The last analysis shows a significant relationship between the two elements. Although management was usually associated with strata buildings, landed residential units also shows that house buyers appreciate the availability of security, safety, and well-maintained developments in their area. This thus affects the house prices significantly. 
MuhamadHilmi Mohamad@Masri, Mohd Farid Sa'ad, Najma Azman, Mohd Hasrol Haffiz Aliasak Residential Building Quality Measurement and The Relationship with House Prices: A Study of Houses in Klang

\section{CONCLUSION}

Based on the findings generated from this research, there are some elements that were deemed as insignificant that can affect the house prices that were functionality, presentation, and community. Whereas the significant elements were the environment, amenities, and management. This shows that with proper empirical research conducted, the relationship between residential building qualities with their prices can be determined, thus helping the stakeholders. House buyers can therefore generally expect much better in terms of the quality level of their houses with the prices that they have paid.

\section{REFERENCES}

Adeoye, D. O. (2016). Challenges of Urban Housing Quality: Insights and Experiences of Akure, Nigeria. Procedia - Social and Behavioral Sciences, 216(October 2015), 260-268. https://doi.org/10.1016/j.sbspro.2015.12.036

Amin, N., Zubaidah, S., Abdul, S., \& Kassim, S. (2015). Enforcement of Housing Law in Malaysia: Issues and Challenges. 2, 230-243.

Behzadfar, M., \& Saneei, M. (2012). Regenerating the historical axes of Isfahan, using urban design dimensions to make places for people (The Case Study of Joibareh Neighbourhood). Procedia - Social and Behavioral Sciences, 51, 728-735. https://doi.org/10.1016/j.sbspro.2012.08.232

Bø, E. E. (2018). Housing match quality and demand: What can we learn from comparing buyer characteristics? Journal of Housing Economics, 41(October 2017), 184199. https://doi.org/10.1016/j.jhe.2018.06.007

Elshater, A. (2012). New Urbanism Principles versus Urban Design Dimensions towards Behavior Performance Efficiency in Egyptian Neighbourhood Unit. Procedia Social and Behavioral Sciences, 68, 826-843. https://doi.org/10.1016/j.sbspro.2012.12.270

Emmanuel, J. B. (2012). "Housing Quality" To the Low-Income Housing Producers in Ogbere, Ibadan, Nigeria. Procedia - Social and Behavioral Sciences, 35(December 2011), 483-494. https://doi.org/10.1016/j.sbspro.2012.02.114

Ezgi, Z., \& Kahraman, H. (2013). Dimensions Of Housing Satisfaction: A Case Study Based on Perceptions Of Rural Migrants Living In Dikmen. Metu Journal of the Faculty of Architecture, 30(01), 1-27. https://doi.org/10.4305/METU.JFA.2013.1.1

Fattah, H. A., Badarulzaman, N., \& Ali, K. (2020). NEIGHBOURHOOD QUALITY ASSESSMENT: A VIEW OF TENURE OWNERSHIP AND MOBILITY DECISIONS IN PENANG, MALAYSIA. Planning Malaysia, 18(1), 92-101. https://doi.org/http://dx.doi.org/10.21837/pm.v18i11.712

Fauzi, S. N. F. M., Yusof, N., \& Abidin, N. Z. (2012). The Relationship of Housing Defects, Occupants' Satisfaction and Loyalty Behavior in Build-Then-Sell Houses. Procedia - Social and Behavioral Sciences, 62, 75-86. https://doi.org/10.1016/j.sbspro.2012.09.014

Gobster, P. H., \& Westphal, L. M. (2004). The human dimensions of urban greenways: planning for recreation and related experiences. Landscape and Urban Planning, 68(2-3), 147-165. https://doi.org/10.1016/S0169-2046(03)00162-2 
Hamzah, N., Ramly, A., Salleh, H., Tawil, N. M., Khoiry, M. A., \& Che Ani, A. I. (2011). The importance of design process in housing quality. Procedia Engineering, 20, 483-489. https://doi.org/10.1016/j.proeng.2011.11.191

Hamzehnejad, M., Dadras, F., \& Yekta, N. H. (2015). ScienceDirect Houses' Physical Features based on Temperament Indicators. Procedia - Social and Behavioral Sciences, 201(February), 317-324. https://doi.org/10.1016/j.sbspro.2015.08.180

Hassan, M. A., Abdullah, Y. A., Omar, D., \& Danial, M. H. (2021). Location housing affordability index: Analysing the relationships. Planning Malaysia, 19(15), 4152. https://doi.org/10.21837/PM.V19I15.923

Hui, E. C. M., Chau, C. K., Pun, L., \& Law, M. Y. (2007). Measuring the neighboring and environmental effects on residential property value: Using spatial weighting matrix. Building and Environment, 42(6), 2333-2343. https://doi.org/10.1016/j.buildenv.2006.05.004

Iwata, S., \& Yamaga, H. (2008). Rental externality, tenure security, and housing quality. Journal of Housing Economics, 17(3), 201-211. https://doi.org/10.1016/j.jhe.2008.06.002

Manley, D., Ham, M. Van, Bailey, N., \& Simpson, L. (2013). Neighbourhood Eff ects or Neighbourhood Based Problems? Springer. https://doi.org/10.1007/978-94-0076695-2

Masri, M. H. b M. @, Nawawi, A. H., Safian, E. E., \& Saleh, A. F. A. (2017). Characteristic Qualities Impacting Landed House Prices: Better Homes, Better Livelihood. Environment-Behaviour Procedings Journal, February, 25-27.

Mohit, M. A., Ibrahim, M., \& Rashid, Y. R. (2010). Assessment of residential satisfaction in newly designed public low-cost housing in Kuala Lumpur, Malaysia. Habitat International, 34(1), 18-27. https://doi.org/10.1016/j.habitatint.2009.04.002

Morenikeji, W., Umaru, E., Pai, H., Jiya, S., Idowu, O., \& Adeleye, B. M. (2017). Spatial analysis of housing quality in Nigeria. International Journal of Sustainable Built Environment, 6(2), 309-316. https://doi.org/10.1016/j.ijsbe.2017.03.008

Mu, S. (2016). Community Building in Social-mix Public Housing: Participatory Planning of Ankang Redevelopment Plan. Procedia - Social and Behavioral Sciences, 222, 755-762. https://doi.org/10.1016/j.sbspro.2016.05.155

Shuid, S. (2015). The housing provision system in Malaysia. Habitat International, 54, 210-223. https://doi.org/10.1016/j.habitatint.2015.11.021

Yazdanfar, S. A. A., \& Nazari, N. (2015). Proposed Physical-environmental Factors Influencing Personal and Social Security in Residential Areas. Procedia - Social and Behavioral Sciences, 201(February), 224-233. https://doi.org/10.1016/j.sbspro.2015.08.171 